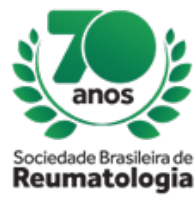

\title{
CORRELATION BETWEEN SOCIODEMOGRAPHIC PROFILE AND PAIN LEVEL IN PATIENTS WITH LOW
} BACK DISC HERNIATION

Francisco Dimitre Rodrigo Pereira Santos (UNIDADE DE ENSINO SUPERIOR DO SUL DO MARANHÃO, Imperatriz, MA, Brasil), Marciene Sousa Cavalcante Costa (UNIDADE DE ENSINO SUPERIOR DO SUL DO MARANHÃO, Imperatriz, MA, Brasil), Hellyangela Bertalha Blascovich (UNIDADE DE ENSINO SUPERIOR DO SUL DO MARANHÃO, Imperatriz, MA, Brasil), Letícia Bezerra Brito (UNIDADE DE ENSINO SUPERIOR DO SUL DO MARANHÃO, Imperatriz, MA, Brasil), Leonardo Boni Souza da Silva (UNIDADE DE ENSINO

SUPERIOR DO SUL DO MARANHÃO, Imperatriz, MA, Brasil), Aparecida Amparo Barros de Deus

(UNIDADE DE ENSINO SUPERIOR DO SUL DO MARANHÃO, Imperatriz, MA, Brasil), Priscila Kellen Nascimento Roza (UNIDADE DE ENSINO SUPERIOR DO SUL DO MARANHÃO, Imperatriz, MA, Brasil),

Raisa Ramos dos Anjos (UNIDADE DE ENSINO SUPERIOR DO SUL DO MARANHÃO, Imperatriz, MA, Brasil), Rosana Matos da Silva (UNIDADE DE ENSINO SUPERIOR DO SUL DO MARANHÃO, Imperatriz, MA, Brasil), Ruan Pablo Lima da Silva (UNIDADE DE ENSINO SUPERIOR DO SUL DO MARANHÃO, Imperatriz, MA, Brasil), Andressa Braga de Araújo (UNIDADE DE ENSINO SUPERIOR DO SUL DO MARANHÃO, Imperatriz, MA, Brasil), Waueverton Bruno Wyllian Nascimento Silva (UNIDADE DE ENSINO SUPERIOR DO SUL DO MARANHÃO, Imperatriz, MA, Brasil), Thyago Duarte Silva (UNIDADE DE ENSINO SUPERIOR DO SUL DO MARANHÃO, Imperatriz, MA, Brasil), Eronilde Silva Gonçalves (UNIDADE DE ENSINO SUPERIOR DO SUL DO MARANHÃO, Imperatriz, MA, Brasil), Fernanda Carneiro Ramos (UNIDADE DE ENSINO SUPERIOR DO SUL DO MARANHÃO, Imperatriz, MA, Brasil), Arthur Barros Fernandes (UNIVERSIDADE FEDERAL DO MARANHÃO, Imperatriz, MA, Brasil)

\section{BACKGROUND}

One of the common disturbances that have increased in recent decades is chronic low back pain. The prevalence of low back pain ranges from 60 to $80 \%$ in total, and individuals between 50 and 59 years of age present the highest prevalence and all people experienced low back pain between the ages of 30 and 50 years old. It is considered incapacitating because it can cause discomfort and limitations at work, in domestic and leisure activities, becoming one of the most common reasons for retirement due to total or partial disability. The objective is to evaluate the correlation between the sociodemographic profile and the level of pain in patients with lumbar disc herniation.

\section{MATERIALS AND METHODS}

This is a cross-sectional study with a quantitative analytical approach. The study was conducted at a private higher education institution in the state of Maranhão, located in the city of Imperatriz-MA. As the population studied is infinite, a sample was determined on demand, being part of this study 54 patients. We included in the sample 44 patients with a diagnosis of lumbar disc hernia, aged over 18 years, living in any state of Brazil. Ten patients were excluded because they did not correctly answer the questionnaire. The data were collected through an online questionnaire, forwarded via social networks. The questionnaire was built through Google Drive, and the information regarding the clinical profile, pain and sociodemographic was collected. The data were tabulate by the Microsoft Excel program, and analyzed by the BioEstat 5.0 program, using the Chi-square test and descriptive statistics.

\section{RESULTS}

The minimum and maximum age of the sample was 20 and 66 years, respectively, first quartile $=27$ and third quartile $=46$, mean $=38$ and standard deviation $=12$; In relation to the years of study, the mean was 15.1 years, a standard deviation of 6.2; Regarding individual income, the minimum was 0 and the maximum was 30.000 , mean $=1,993$, standard deviation $=942$. The correlation between the level of pain 
in patients with lumbar disc herniation and the years of study and individual income were statistically significant $(p<0.005)$, in contrast, the level of pain and age had no correlation $(p=0.2602)$.

\section{CONCLUSION}

There is a correlation between the level of pain in patients with lumbar disc herniation and the years of schooling and individual income. The correlation between age and pain level did not present significant significance. 